Трончук I. С., доктор сільськогосподарських наук,

Рак Т. М., кандидат сільськогосподарських наук,

Чижанська Н. В., кандидат біологічних наук

Полтавська державна аграрна академія

\title{
СТРУКТУРА І ПОЖИВНІСТЬ РАЦІОНІВ ДЛЯ ДІЙНИХ КОРІВ ІЗ РІЧНИМ НАДОЄМ МОЛОКА ВІД ШЕСТИ ДО ДЕВ'ЯТИ ТИСЯЧ КІЛОГРАМІВ
}

\author{
Рецензент - кандидат ветеринарних наук М. В. Лисенко
}

\begin{abstract}
Розроблена перспективна фізіологічно та економічно обтрунтована структура рачіонів для високопродуктивних дійних корів. Проведені авторами статті дослідження показали, щчо при високих добових надоях варто з метою нормального споживання необхідної кількості кормів обмежувати у рачіонах кількість кукурудзяного силосу до 25-30 кг на голову на добу, а концентрованих кормів збільиити до 46-54\% за поживністю. Дано пропозиції щуодо організації повноцінної годівлі дійних корів протягом року, щзо гарантує виробництво високоякісного рентабельного молока. Рівень інтенсифікачії: річні надої молока 60009000 кг; витрати кормів на 1 кг молока9-10 МДж обмінної енертії.
\end{abstract}

Ключові слова: корови, молоко, корми, рацуіони, структура, годівля, зима, літо.

Постановка питання. Висока молочна продуктивність корів можлива тільки в умовах нормальної годівлі й необхідної концентрації обмінної енергії та поживних речовин у сухій речовині раціонів. Зокрема, за добових надоїв молока 20 кг поживність 1 кг сухої речовини раціону має рівнятися 9,4 МДж обмінної енергіï, а при 40 кг - 11,2, тобто на $19 \%$ більше. Вміст перетравного протеїну, відповідно, підвищується від 80 до 115 г, або на $44 \%$.

У той же час загальна кількість сирої клітковини у раціонах має залишатися на рівні 4500 грамів. Тому за добових надоїв молока 20 кг сира клітковина в 1 кг сухої речовини раціонів повинна бути не більше $24 \%$, а при 40 кг не нижче $17 \%[2,3]$.

У зв'язку з цим слід уточнити структуру раціонів для господарств із річними надоями молока 6000 кг і більше та розробити рекомендації по складу раціонів на зимовий і літній періоди у Лісостепу України.

Аналіз основних досліджень і публікацій, у яких започатковано розв'язання проблеми. Робота має в цілому оглядовий характер. У ній узагальнено експериментальні дані вітчизняних і зарубіжних учених (Леонард Дурст, 2003; Симо- нов Г. А., 2005; Гармаш О., 2006; Трончук I. C., 2006; Ібатулін I. І., 2007; Хольгер Брюкнер, 2010 та ін.) та досягнення практичного передового досвіду кращих господарств щодо годівлі дійних корів за останні 10 років, зокрема норми годівлі, значення концентрації поживних речовин у забезпеченні високої молочної продуктивності корів до рівня 6-9 тисяч кілограмів за лактацію.

Мета досліджень і методика їх проведення: на основі аналізу літературних джерел розповісти про особливості та структуру раціонів годівлі корів у зоні лісостепу України. У цій зоні в зимовий період використовуються такі основні соковиті корми, як кукурудзяний силос та кормові буряки. Кукурудзяний силос, завдяки впровадженню сучасних передових технологій вирощування кукурудзи, став основним соковитим кормом як у зимовий, так і в літній періоди року. Урожайність зеленої маси кукурудзи в молочновосковій стиглості досягла 400-500 ц, а завдяки змішаним посівам із соєю вміст перетравного протеїну збільшився від 14 до 18-20 г у кілограмі корму, що забезпечує вихід із гектара посіву 340-425 центнерів силосу. Найдоцільніше закладати його в наземні траншеї або в поліетиленові шланги.

Проте у цьому кормі високий вміст сирої клітковини - близько 75 г у кілограмі корму, а в сухій речовині - до $30 \%$. Ця клітковина має високий вміст лігніну, через що перетравлюється всього на $40 \%$, однак є важливим фактором нормального перетравлення всіх інших поживних речовин раціонів і бродильних процесів у чотирьохкамерному шлунку. Фізіологічною добовою нормою сирої клітковини для нормального травлення й синтезу молока жирністю 3,6-4,0\% для корів молочних порід живою масою 600 кг є 4500 г. За меншої кількості (менше $17 \%$ ) у сухій речовині кормів порушуються процеси травлення, підвищується кислотність кормової маси у рубці, що за тривалої годівлі викликає ацидоз, спад надоїв молока, зменшення в ньому вмісту жиру [7]. 
За більшого вмісту в раціоні сирої клітковини (понад $25 \%$ ) у сухій речовині погіршується поїдання кормів і їх перетравлення, що є основною причиною низьких надоїв молока як у зимовий, так і в літній періоди [2, 4].

Кормові буряки - високоврожайна кормова культура, яка при сучасній агротехніці забезпечує вихід коренеплодів від 500 до 1000 ц/га. Це традиційний цінний молокогінний i дієтичний корм, що дає можливість одержувати високі надої молока у зимовий період та забезпечувати його високу якість - як питного молока, так i основних продуктів його переробки (масла, сиру тощо).

В одному кілограмі кормових буряків міститься 120 г сухих речовин, із яких на легкоферментовані вуглеводи припадає $72 \%$, сиру клітковину (перетравність 47-50\%) - 7,5\% і сирий протеїн - 10,8\%. Вони активізують мікробіологічні процеси у передшлунках, у результаті чого кормова маса збагачується на біологічно цінний білок мікробного походження та вітаміни групи В, стимулюють виділення травних соків, що сприяє підвищенню перетравності кормів. Пектинові речовини буряків сприяють поїданню кормів та виведенню з організму шкідливих продуктів обміну речовин [2].

У заземлених сховищах, обладнаних вентиляцією, вони можуть надійно зберігатися й використовуватися до травня. Зважаючи на високу собівартість буряків, їх доцільно використовувати дійним коровам разом із кукурудзяним силосом у співвідношенні: на 25-30 кг силосу, 10-15 кг буряків.

Кількість інших кормів та структуру раціонів визначаємо $з$ урахуванням добової потреби у сирій клітковині, яка прийнята у кількості 4500 г для всіх корів із добовими надоями від 20 до 40 кг. Виходячи з цього, коровам, як правило, на голову на добу згодовують по 4-5 кг сіна і 6-8 кг сінажу із багаторічних трав та концентровані корми у вигляді комбікормів-концентратів.

Результати досліджень. Із метою уточнення структури раціонів для дійних корів у зимовий період використали діючі норми годівлі при добових надоях молока 20, 30 і 40 кг, визначивши за цими даними концентрацію поживних речовин в 1 кг сухих речовин (табл. 1).

Із даних таблиці видно, що з підвищенням добових надоїв молока добова потреба всіх видів поживних речовин, окрім сирої клітковини, збільшується. Підвищується також і їх концентрація у сухій речовині, а саме: вміст обмінної енерriї зростає від 9,36 до 11,21 МДж, перетравного протеїну - від 80 до 115 г, крохмалю від 108 до 195 г, цукрів від 82 до 126 г, сирого жиру - від 26 до 42 грам.

На цій основі камеральним шляхом - із урахуванням досвіду наших кращих господарств спроектували по три раціони для корів із добовим надоєм 20, 30 і 40 кг по двох варіантах: iз включенням у першому кукурудзяного силосу i кормових буряків, у другому - лише кукурудзяного силосу (табл. 2).

Як видно із раціонів, по всіх поживних речовинах вони відповідають існуючим нормам годівлі, забезпечуючи необхідну концентрацію всіх поживних речовин, наведену у таблиці 1. Це відноситься й до сирої клітковини, а саме: у перших трьох раціонах вміст її знаходиться на рівні 228 , 210 і 178 г, у других трьох, відповідно, 245, 210 i 186 грам.

\section{1. Норми годівлі дійних корів живою масою 600 кг та концентрація поживних речовин} у 1 кг сухої речовини раціонів

\begin{tabular}{|c|c|c|c|c|c|c|c|c|c|c|c|}
\hline 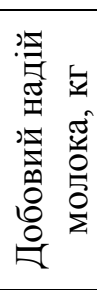 & 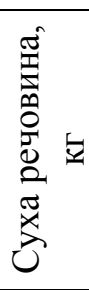 & 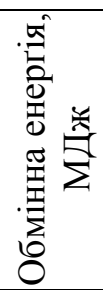 & 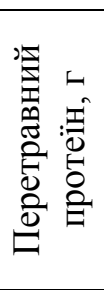 & 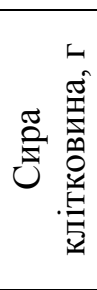 & 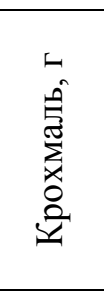 & $\stackrel{\breve{\Delta}}{\stackrel{5}{5}}$ & 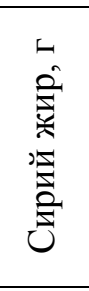 & 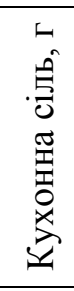 & $\stackrel{\tilde{v}}{\tilde{f}}$ & $\stackrel{4}{n}$ & 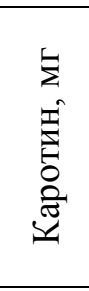 \\
\hline 20 & 18,9 & 177 & 1510 & 4540 & 2040 & 1360 & 485 & 110 & 110 & 78 & 680 \\
\hline 30 & 22,0 & 237 & 2280 & 4500 & 3590 & 2395 & 810 & 150 & 150 & 108 & 1010 \\
\hline 40 & 26,4 & 296 & 3045 & 4480 & 5155 & 3325 & 1110 & 190 & 190 & 138 & 1385 \\
\hline \multicolumn{12}{|c|}{ Концентрація поживних речовин у 1 кг сухої речовини } \\
\hline 20 & - & 9,36 & 80 & 240 & 108 & 72 & 26 & 5,8 & 5,8 & 4,1 & 36 \\
\hline 30 & - & 10,77 & 104 & 205 & 163 & 109 & 37 & 6,8 & 6,8 & 4,9 & 46 \\
\hline 40 & - & 11,21 & 115 & 170 & 195 & 126 & 42 & 7,2 & 7,2 & 5,7 & 52 \\
\hline
\end{tabular}


СІЛЬСЬКЕ ГОСПОДАРСТВО. ТВАРИННИЦТВО

2. Раціони годівлі дійних корів у зимовий період на голову на добу, кг

\begin{tabular}{|c|c|c|c|c|c|c|}
\hline \multirow{3}{*}{ Показники } & \multicolumn{3}{|c|}{$\begin{array}{c}\text { Раціони } 3 \text { кормовими буряками } \\
\text { (жомом) }\end{array}$} & \multicolumn{3}{|c|}{ Раціони без цих кормів } \\
\hline & \multicolumn{6}{|c|}{ Добові надої молока, кг } \\
\hline & 20 & 30 & 40 & 20 & 30 & 40 \\
\hline Сіно лучне & 3,6 & 4,5 & 4,3 & 3,6 & 4,5 & 4,3 \\
\hline $\begin{array}{c}\text { Сінаж багаторічних } \\
\text { трав }\end{array}$ & 6,4 & 7,4 & 7,8 & 6,4 & 7,4 & 7,8 \\
\hline Кукурудзяний силос & 32,0 & 27,0 & 26,0 & 32,0 & 32,0 & 32,0 \\
\hline Кормовий буряк & 11,0 & 18,7 & 23,3 & - & - & - \\
\hline Комбікорм & 4,7 & 7,9 & 13,0 & 5,0 & 9,9 & 15,0 \\
\hline Кухонна сіль & 0,06 & 0,07 & 0,07 & 0,06 & 0,05 & 0,04 \\
\hline \multicolumn{7}{|c|}{ Поживність раціонів } \\
\hline Суха речовина, кг & 17,707 & 23,122 & 28,077 & 18,375 & 23,599 & 28,285 \\
\hline $\begin{array}{l}\text { Обмінна енергія, } \\
\text { МДж }\end{array}$ & 177 & 237 & 296 & 177 & 237 & 296 \\
\hline $\begin{array}{c}\text { Перетравний } \\
\text { протеїн, Г }\end{array}$ & 1571 & 2316 & 3054 & 1600 & 2295 & 3038 \\
\hline Сира клітковина, г & 4042 & 4869 & 4997 & 4511 & 4948 & 5272 \\
\hline Крохмаль, г & 2561 & 3853 & 6036 & 2833 & 4713 & 6885 \\
\hline Цукри, г & 986 & 1417 & 1735 & 561 & 763 & 950 \\
\hline Сирий жир, г & 598 & 842 & 1179 & 588 & 905 & 1205 \\
\hline Кухонна сіль, г & 110 & 150 & 190 & 110 & 150 & 190 \\
\hline Кальцій, г & 119 & 155 & 186 & 124 & 163 & 195 \\
\hline Фосфор, Г & 77 & 116 & 139 & 77 & 114 & 143 \\
\hline Каротин, мг & 829 & 929 & 937 & 853 & 1013 & 1061 \\
\hline \multicolumn{7}{|c|}{ Витрати кормів на 1 кг молока } \\
\hline $\begin{array}{l}\text { Обмінна енергія, } \\
\text { МДж }\end{array}$ & 8,85 & 7,90 & 7,40 & 8,85 & 7,90 & 7,40 \\
\hline $\begin{array}{c}\text { Перетравний } \\
\text { протеїн, Г }\end{array}$ & 78 & 77 & 76 & 80 & 77 & 76 \\
\hline Комбікорми, г & 235 & 263 & 325 & 250 & 330 & 375 \\
\hline
\end{tabular}

Вміст перетравного протеїну відповідає існуючим нормам, а в одному кілограмі сухої речовини, відповідно, рівняється 89, 100 та 109 г, у раціонах із кукурудзяним силосом - 87, 92 та 107 грам.

Вміст легкоферментованих вуглеводів (крохмаль, цукри) у перших трьох раціонах становить 90, 88 і 92, у других - 100, 92 і $92 \%$ від існуючих норм. Вміст сирого жиру дещо вищий від них, а саме: у перших трьох раціонах 123, 104 i $107 \%$, у других - 121, 112 і $108 \%$. Отже, на основі цих розробок рекомендуємо виробництву наступну структуру раціонів для дійних корів на зимовий період (табл. 3).

Вважаємо доцільним сіно і сінаж використовувати в однаковій оптимальній кількості, кукурудзяний силос у перших трьох випадках також у цій же кількості, а при відсутності кормових буряків (жому) в максимальній кількості - бли- зько 32 кг на голову за добу, але обмежуватись оптимальною кількістю сирої клітковини в раціоні (не більше 5000 г). У цих умовах у структурі раціонів із кукурудзяним силосом і кормовими буряками концентровані корми мають складати при добових надоях 20 кг $28 \%, 30$ кг - 35 і 40 кг - $46 \%$ за поживністю, а лише із соковитих кормів кукурудзяним силосом, відповідно, 30, 44 i $54 \%$, тобто на 1 кг молока комбікормів концентратів 235, 263, 325, 250, 330 та 375 грам.

За кордоном у кращих господарствах у структурі раціонів концентровані корми за поживністю доводяться до 60 \% і більше [9]. Так, у Росії у племзаводі „Пушкінське” на поголів'ї 700 корів одержано річний надій молока 9035 кг при $61,4 \%$ концентрованих кормів за поживністю [5], або по 432 г на 1 кг молока.

Даємо прогноз і поживності комбікормівконцентратів (табл. 4). Вважаємо, що поживність 
СІЛЬСЬКЕ ГОСПОДАРСТВО. ТВАРИННИЦТВО

3. Структура раціонів для дійних корів у зимовий період, \% за поживністю

\begin{tabular}{|c|c|c|c|c|c|c|}
\hline \multirow{3}{*}{ Корми } & Раціони & ІМИ & жомом) & & eз L & \\
\hline & \multicolumn{6}{|c|}{ добові надої молока, кг } \\
\hline & 20 & 30 & 40 & 20 & 30 & 40 \\
\hline Сіно & 14 & 13 & 10 & 14 & 13 & 10 \\
\hline Сінаж & 15 & 13 & 11 & 15 & 13 & 11 \\
\hline $\begin{array}{l}\text { Кукурудзя- } \\
\text { ний силос }\end{array}$ & 32 & 26 & 20 & 41 & 30 & 25 \\
\hline $\begin{array}{c}\text { Кормовий } \\
\text { буряк }\end{array}$ & 11 & 13 & 13 & - & - & - \\
\hline Комбікорм & 28 & 35 & 46 & 30 & 44 & 54 \\
\hline
\end{tabular}

4. Поживність 1 кг комбікормів (87\% суха речовина)

\begin{tabular}{|c|c|c|c|c|c|c|c|c|c|}
\hline $\begin{array}{l}\text { Добовий } \\
\text { надій, кг }\end{array}$ & $\begin{array}{c}\text { Обмінна } \\
\text { енергія, } \\
\text { МДж }\end{array}$ & $\begin{array}{c}\text { Перетравний } \\
\text { протеїн, г }\end{array}$ & $\begin{array}{l}\text { Сира кліт- } \\
\text { ковина, г }\end{array}$ & $\begin{array}{c}\text { Крохмаль, } \\
\Gamma\end{array}$ & $\begin{array}{c}\text { Цукри, } \\
\text { г }\end{array}$ & $\begin{array}{l}\text { Сирий } \\
\text { жир, г }\end{array}$ & $\begin{array}{c}\text { Кухонна } \\
\text { сіль, г }\end{array}$ & $\begin{array}{l}\text { Каль- } \\
\text { цій, г }\end{array}$ & $\begin{array}{l}\text { Фос- } \\
\text { фop, I }\end{array}$ \\
\hline \multicolumn{10}{|c|}{ Для раціонів із кормовими буряками } \\
\hline 20 & 10,5 & 100 & 70 & 480 & 35 & 30 & 10 & 6 & 10 \\
\hline 30 & 10,5 & 110 & 70 & 440 & 35 & 40 & 10 & 6 & 10 \\
\hline 40 & 10,5 & 130 & 55 & 435 & 35 & 50 & 10 & 6 & 7,5 \\
\hline \multicolumn{10}{|c|}{ Для раціонів без кормових буряків } \\
\hline 20 & 10,5 & 100 & 70 & 500 & 35 & 30 & 10 & 6 & 10 \\
\hline 30 & 10,5 & 110 & 50 & 440 & 35 & 38 & 10 & 6 & 8,5 \\
\hline 40 & 10,5 & 120 & 50 & 435 & 35 & 43 & 10 & 6 & 7,5 \\
\hline
\end{tabular}

1 кг таких комбікормів має бути не менше 10,5 МДж обмінної енергії, проте з різним вмістом перетравного протеїну в залежності від добового надою корів - від 100 до 130 г, сирого жиру - від 30 до 50 грам. Звичайно, кращим білковим компонентом комбікормів слід вважати екструдат сої в кількості 10-15\% за масою [1-6]. Достатня мінеральна забезпеченість 1 кг комбікормів така: кухонна сіль - 10 г, кальцій -6 г, фосфор - 10-7,5 грам. Нормальний вміст вітамінів та мікроелементів забезпечується включенням у комбікорми рекомендованих для Лісостепу України преміксів.

Щодо структури раціонів у літній період, то зелені корми у кількості 65-70 кг на голову на добу можуть повністю замінити грубі й соковиті корми. Комбікорми слід згодовувати у такій же кількості, відповідно добового надою у кількості 5, 8 та 13 кг. За такої годівлі загальна добова кількість сирої клітковини також не перевищуватиме фізіологічну норму - 4500 г, що гарантуватиме нормальне споживання всіх кормів і високу молочність корів.

Зелені, соковиті та грубі корми подрібнюють, змішують і здобрюють комбікормами з розрахунку 2-3 кг на голову на добу і в такому розсипному вигляді згодовують 2-3 рази щодобово. Основну кількість комбікормів згодовують інди- відуально по 2-3 кг при доїнні $[4,8]$.

Середньодобове споживання сухої речовини кормів буде досить високим і становитиме на кожних 100 кг живої маси корів за добових надоїв 20 кг - 3 кг, при 30 кг - 3,8, при 40 кг - 4,7 кг $[8,9]$.

3 урахуванням потреби у кормах за сухостійний 60-денний період загальна річна потреба у кормах на корову 3 річним надоєм молока 6000 кг становить 62500 МДж обмінної енергії, на 9000 кг - 82000, або на 1 кг молока, відповідно, 10,2 і 9 МДж обмінної енергії.

\section{Висновки:}

1. Високі річні надої молока на рівні 6000 9000 кг вимагають впровадження при годівлі дійних корів раціонів із високою концентрацією обмінної енергії та поживних речовин у сухій речовині. Чим надої вищі, тим при оптимальній кількості в раціонах грубих, соковитих і зелених кормів у структурі раціонів має бути більше концентрованих кормів. Кількість їх при добових надоях від 20 до 40 кг збільшується від 28-30 до 46-54 \%.

2. Концентровані корми слід використовувати у вигляді комбікормів-концентратів. Поживність 1 кг їх має становити не менше 10,5 МДж обмінної енергії, а вміст перетравного протеїну зі збільшенням добового надою молока від 20 до 40 кг підви- 
щуватиметься від 100 до 120-130 грамів.

3. Грубі, соковиті та зелені корми подрібнюють, змішують із добавкою 1-1,5 кг комбікормів

\section{БІБЛІОГРАФІЯ}

1. Гармаш О. Раціон багатий - молокопродуктивність вища. - К.: Тваринництво України, 2006. - № 3. - С. 27-29.

2. Ібатуллін І. І., Мельничук Д. О., Богданов Г. О. [ma iн.]. Годівля сільськогосподарських тварин. - Вінниця: Нова Книга. - 2007. - 612 с.

3. Калашников А. П., Клейменов Н. И. Нормы и рационы кормления сельскохозяйственных животных. Справочное пособие. - М.: Агропромиздат. $-1985 .-350 \mathrm{c}$.

4. Леонард Дурст, Маргит Виттман. Кормление основных видов сельскохозяйственных животных. - Винница: Нова Книга. - 2003. -384 с.

5. Симонов Г.А., Сабурин В.А., Коваль Ю. В. $[u$ дp.]. Опыт создания высокопродуктивных молочных стад. - М.: Зоотехния. - 2005. - № 1. - і згодовують 2-3 рази на добу. Більшу кількість комбікормів індивідуально задають коровам, по 2-3 кг при кожному доїнні.

C. 11-15.

6. Трончук I. С., Бердник I. Ю. Вплив концентрації обмінної енергії та поживних речовин у сухій речовині раціонів на продуктивність дійних корів. - Вісник Полтавської державної аграрної академії, 2006. - № 2. - С. 86-90.

7. Шалатонов И. С. Нарушение рубцового пищеварения у высокопродуктивных коров при силосно-сенажно-концентратном типе кормления. - М.: Зоотехния. - 2005. - № 4. - С. 12-13.

8. Хольгер Брюкнер. Поиск оптимальной кратности доения - К.: Ефективне тваринництво. 2010. - № 1. - C. 26-27.

9. Brade $W$., Gutglegch M., Hansen E. Ordnungsdemahe Ringer Haltung. - Hannover. - 1999. - 103 p. 